\title{
The act of charity, part of the Social Economy
}

\author{
Dragos RADULESCU Faculty of International Business \\ "Dimitrie Cantemir" Christian University \\ Email: dmradulescu@yahoo.com \\ Cristina BALACEANU \\ Faculty of Marketing \\ "Dimitrie Cantemir" Christian University \\ Email: movitea@yahoo.com
}

\begin{abstract}
The pleasure to offer has no connection with richness or welfare, it occurs when you realize that your neighbor is more afflicted than you, that you are more blessed by God or you want to be at peace with yourself by helping others in order to thank or to seek real help, of divine, superfluous nature.

Although pleasure does not interfere with need, it brings about a good feeling, while the need seems to be embodied in our nature as we cannot live without it and now and then we make them merge to combine feelings with reason.

Offering is an act without expectation for reward, although the benefits occur after a while, being both material (reward) and especially immaterial, a service or a gesture of gratefulness. We offer when we love, we give because we need to establish moral and social values for our peers to perceive the approach, understanding, tolerance and solidarity.
\end{abstract}

KEY WORDS Social values, social entrepreneurship, social economy.

DOI: 10.6007/IJAREMS/v2-i4/119 URL: http://dx.doi.org/10.6007/IJAREMS/v2-i4/119

\section{Introduction}

However the function of moral values is to guide society's or social groups' action and their role is to help us choose, finding the goals for us. Regardless its various definitions, the good is considered an evaluation principle: to make decisions related to human life.

Although morality is above all indisputable, one considers that it determines the values being a universal social fact as shown by the Latin etymology (mores $=$ morals). Any society knows a set of rules of conduct and values; there is a ubiquitous opposition between good and evil (Radulescu, 2012). 
Nevertheless, when it comes to morality, the problem is to know how to assess the truth of our evaluations, as due to the role of morality to distinguish the good from the evil and choose the good, there should be a problem of moral values, of eventual justification of our values.

Morality is above all this anxiety experienced by itself against its foundation, expressed in the existence of "the scruple". The decision of acting well is certainly followed by the question: "How will I know if I did right?"

A choice is imperative since arbitrations are more difficult, the decisions are uncertain and values are sometimes contradictory. Far from being a soothe experience or a comfortable, calm conscience, the desire to act well makes us doubt that we have done enough. Finally, doing enough means doing too little. Enough proves to be insufficient for those who seek justice where cannot be found in real life.

There is a thirst for absolute morality without claims to be compatible with here and now, with concrete situations where it is applied. In this respect, the moral experience is that of an unfortunate conscience undergoing the gap between what you are and what you must be living reality as a continuous deception.

If real is what opposes to the ideal, how can I be sure that the values which should help me choose will not actually prevent me from doing it? How can I be sure that in case I accomplish different tasks, I shall not cause conflicts that morality itself would be unable to solve?

The moral experience proves to be unhappy as it is always accompanied by uncertainty regarding our values and morality.

The moral deed is classically defined as an unselfish deed, meaning that we no longer consider happiness as a supreme good; moreover we sacrifice what we might make us happy - the satisfaction of our interests - ideal requirements of virtue, the pursuit of uninterested goals.

To be moral means to be able to consider the triumph of good more important than its practical function, means to do well, even in situations where it is contrary to our wishes .

The current society records numerous drawbacks in education and the social area, caused by poverty, lack of welfare, perpetuation and intensification of negative phenomena such as violence, school dropout, premature aging, with immediate effects on community and lifestyle .

Thus, to improve the status quo is imperative to involve the society through social responsibility programs generally, volunteering, and development of social entrepreneurship and of social economy.

\section{Social entrepreneurship}

Social entrepreneurship is a social entrepreneur's activity, which runs profit-making activities to support social causes. Social entrepreneurship cannot be defined by a specific organizational form, characteristic to it and should be understood as a multidimensional and dynamic structure swinging between intersection areas of the public, private and nonprofit fields. This form of entrepreneurship has been 
developed especially alongside with the failure of governments regarding the citizens' need for social entrepreneurship. Its mission is to discover what does not work in the government or business sector and solve the problem by:

- Change of system

- Solution dissemination

- Societies' determination to find and pursue new ways of taking action

- Education and support for the entrepreneurial talents

Therefore, the social entrepreneurship can mean almost anything, from the founder of a nonprofit association to the person who, by starting a business, takes a social responsibility of his operating and approaching way within the respective enterprise. The novelty of the concept lies in blurring the boundaries between the business and the social sector. Besides the non -profit organizations, the social entrepreneurship includes activities aimed at making a profit, such as community development banks and organizations that combine elements specific to business and non -profit sector (ex. social shelters dealing with surcharged professional retraining activities and job offers ). Social entrepreneurs create social value through a continuous process of innovation and capitalization on new opportunities, with the first benefit of society at the expense of their own benefit.

The Social Entrepreneurship is an important step towards social justice and sustainable development in Europe, a contribution to concerted action to eradicate global poverty by 2030 . To this end, social entrepreneurship has the following goals:

- Gaining profit in behalf of a disadvantaged social group - the basic principle of social entrepreneurship.

- Implementation of ethical, sustainable economic activities which create jobs for disadvantaged people

- Development of legislative package for social enterprises in Romania.

- Differentiation among the social entrepreneurship, corporate social responsibility and the socially responsible investments, by making decisions.

- Institutional affiliation: The activities of social entrepreneurship may be performed both NGOs and cooperatives (handicraft, agricultural, consumer, cooperative banks, authorized protected units), mutual associations and unions.

To highlight the mission of social entrepreneurship and its vital role in social development and economic progress we present a summary of the benefits it generates in communities where it operates: 
- Increase the number of employees. Social entrepreneurship activities provide jobs and opportunities. At the same time, it increases employment and training opportunities for disadvantaged groups or they become self- connection between the labor market and unemployment.

- Innovation and creation of new goods and services for the social needs. Similar to the entrepreneurship, the social enterprises apply and develop innovation to achieve development of new goods and services. Social issues most commonly addressed by social enterprises at this time are: HIV / AIDS, mental or physical disability, illiteracy, drug abuse etc. .

- It creates social capital to meet the social and economic sustainable development.

- It promotes social justice by addressing the needs of disadvantaged people. Social undertakings raise social problems and aim at trying to achieve a continuous and sustainable impact rather through their social mission than through profit maximization.

- Demonstrate a keen sense of responsibility to the people they serve and the consequences of actions taken. Since the market laws fail automatically remove ineffective social processes, the social entrepreneurs seek to ensure that their businesses are always primarily for the benefit of community. This involves trying to understand people, to correctly estimate the needs and advantages of those going to benefit from their actions, this being most often perceived as strong ties to the communities they serve.

Essentially, social entrepreneurship serves the objectives of the social economy. The social economy is that form of economy focused on the human being's needs and limits, it admits both the state's failure in the redistribution of own financial resources and market failure regarding the efficient allocation of economic goods. Social economy is responsible for and relies on principles of solidarity and individual involvement in the process of active citizenship and societal community in managing the inner malfunctions, giving it a number of attributes (Zamfir, 2012)

- Generates quality jobs and a better living standard ;

- Provides a framework for the emergence of new businesses and new types of work ;

- Plays an important role in local development and social cohesion ;

- Is socially responsible ;

- Represents a factor of democracy;

- Contributes to the stability and pluralism of the economic markets ;

- Creates a new mentality that contributes to the achievement of higher social conscience ; 
- Meets the EU priorities and strategic objectives: social cohesion, full employment, the fight against poverty, participatory democracy, better governance, sustainable development.

As individuals, the social entrepreneurs play the role of change agents in the social sector by:

- Adopting a mission to create and sustain social value (not just private ) ;

- Identifying and seeking new opportunities to fulfill this mission ;

- Engaging in a process of steady innovation, adaptation and learning ;

- Acting in a bold manner, regardless the limited resources available to them.

Social entrepreneurs are reformers and people who revolutionize their environment with a social mission at the same time. They seek to make systematic changes and sustainable improvements, focusing on the true causes of social problems, trying to treat the symptoms.

The social mission a social entrepreneur undertakes is fundamental. This mission makes the difference between a social entrepreneur and a business one or even a socially responsible company. Making profit or meeting the consumer needs can be among the objectives of a social entrepreneur, but they are nothing but ways to achieve the social purpose, social services.

The Dictionary of Social Policies defines social services as instruments for achieving social goals, redistributive ones, representing those public services aiming at increasing social welfare. As defined by some authors, the social services represent activities of social workers or other professionals who help people prevent addiction, strengthen family relations and restore the social functioning of individuals, families and communities.

Wherever most people see problems, social entrepreneurs see opportunities; in their actions, they are less encouraged by the perception of a social need or compassion and more by the idea to improve things and are determined to implement this vision. Social entrepreneurship comes to complete and support the social workers' work.

A simplified definition of the social enterprise places the entity on the boundary between business sector and traditional non -profit sector, the social organization therefore looking like a hybrid. The change in the expectations of non-profit organizations to reach a wider social impact and at the same time to diversify their funding sources has been considered as a major factor in the emergence of the non -profit hybrid, both for profit and non- profit.

At this intersection of the business and traditional non -profit sector we find the social enterprises. In some cases, if a business has a mission and social involvement, working together with a nongovernmental organization that it financially supports, may be considered a social enterprise. However, 
there are not assessed as social enterprises the firms whose activities involve corporate social responsibility, even if these financially support an NGO.

There are two main criteria for the classification of social enterprises: according to the mission orientation and to the social program integration level in trading. In terms of mission orientation there are three types of social enterprises:

\section{Social enterprises focused on mission}

The Social enterprise is created for the sole reason of promoting its mission using a self-financing model. An example of this type of organization is the type of organizations employing persons with disabilities or the microfinance institutions.

From the point of view of the social program integration in trade, the social programs and business activities are the same. Non-governmental organizations create specifically integrated social enterprises for purposes concerning programs. Social programs are self- funded by the enterprises undertakings and thus the employed social enterprise carries on sustainability program. Due to their mission, most social enterprises are structured as non- profits to protect themselves against the mission changing, but may function as profit organizations.

\section{Social enterprises associated to the mission}

The company is associated with the organization's mission or with the basic social services. This type of organization is based on the similar qualities, creating social value for programs and generating economic value to financially support social programs and / or operating expenses

Regarding the level of social program integration in trading activity, in this pattern, the social programs overlap with activities generating profits, often sharing costs and resources (integrated pattern). The organizations create social enterprises as a funding mechanism to support non- profit operations and activities related to the mission.

In many cases, the integrated social enterprise extends or strengthens the organization's mission, giving it the opportunity to achieve a greater social impact.

\section{Social enterprises without connection to the mission}

The social enterprise is not related to the organization's mission or it is meant to encourage no other mission but the one generating revenue for their social programs and operating costs. Social enterprises can operate in an industry that is not related to the sector of the non-profit parent organization, the profit potential being the reason for its existence in order to ensure the non -profit association conducting business.

The social enterprise pattern without connection to the organization's Mission is a foreign model of social enterprise, taking into account the level of social programs integration in profit -generating 
activity. This model assumes that non-profit organizations create social enterprises to fund social services and / or operating costs. The relationship between income generating activities and social programs is supportive, the former offering unlimited funding to non- profit parent organization. Usually, foreign social enterprises have no connection to the organization's mission; the profitgenerating activities are more compelled to generate revenue for social programs or operating costs rather than to promote the mission.

As the term social enterprise is not defined by law in Romania, there are no statistics to provide information regarding the three types of enterprises. Presently, the only categories of entities with social activities are the public suppliers of the Ministry of Labor and Social Solidarity of Romania and the nongovernmental organizations.

Social economy is not a novelty; it is a natural continuation of a strong manufacturing sector developed in the last century, especially in Romania, as a former Communist country, with the community's demonstrations of solidarity and social cohesion for a number of social groups with very diverse vulnerabilities. Currently, the imperative to develop the social economy is complex, from the job offers for disadvantaged people to the implementation of a conduct and action framework of the groups generally vulnerable on the markets and particularly on the labor market.

Romania is a country whose strategic vision does not tally with the development trends of the global economy on the one hand, and with the domestic real life, on the other hand. With a rapidly rising unemployment, and an inefficient allocation of budgetary resources, but also with a substantial decrease in the tax base caused by the instability of the economic environment and especially of the political one, the idea of setting up new jobs is really a utopia.

\section{Conclusion}

Social entrepreneurship opens new possibilities for local development, where one community builds its own development strategy based on own resources and on the community members' identified needs. Making social economy and social entrepreneurship on a small scale are examples of good practice for other communities without compulsory implementation on macroeconomic scale. Social economy implies the identification of every employee's needs and shortages, his problems being solved through the community involvement and solution identification, most of the times a personal one. This defines the social entrepreneurship: the idea of doing good things to himself and the community, to make your destiny available to others not for sharing it, but for providing an example of involvement and creation of a specific activity that generates wealth.

\section{References}

Cristina Bălăceanu, 2012, Transition from governing to governance, Pro Universitaria Publ. House, Bucharest 
Cristina Bălăceanu, Diana Apostol, 2013, Lifestyle and eco-eficiență, in Social Economic Debates Review, nr. 1/2013, Rosetti International Publishing House, http://www.economicdebates.ro/pagina_principala.php

Larrz C. Farrell, 2008, How can I become an entrepreneur?, Curtea Veche Publ.House, Bucharest

Marius Ghinea, 2011, Entrepreneurship: the pathway from ideas to opportunities and business success, Universul Juridic Publ. House, Bucharest

Cristina Loghin, 2012., Social economy - a challenge, in Social Economic Debates Review, nr. 1/2012, Rosetti International Publishing House, http://www.economic-debates.ro/pagina_principala.php

Cosmin Stoica, 2013, The Role of Economist in Economic life, International Joumal of Academic Research in Economics and Management Science, http://www.hrmars.com/admin/pics/1720.pdf

Muhammad Yunus, Social business development, a Curtea Veche Publ.House, Bucharest, 2010

Zamfir E., Studies of social economy, Romanian Academy, the Life Quality Institute 2012

Mihaela Vlăsceanu, Social economy and entrepreneurship, Polirom Publ.House, Iaşi, 2010

Rădulescu D.M. (2012) - Moral - The social dimension of the right, International Journal of Academic Research in Economics and Management Science (IJAREMS) Vol. 1, Nr. 06/2012 54-59 